\title{
Effect of Internal Control System on Risk Assessment in the Nigeria Public Sector (A Study Answer Prepared)
}

\author{
Muhammad Barkindo Umar ${ }^{1 *}$, Jeremiah Yusuf Karfe ${ }^{2,}$ Gambo Sule $^{3}$, Ado Ahmed ${ }^{4}$ \\ Department of Accounting and Finance, Faculty of Management Science, Abubakar Tafawa Balewa University Bauchi, Nigeria
}

DOI: $10.36348 /$ SB.2019.v05i12.005

| Received: 04.12.2019 | Accepted: 11.12.2019 | Published: 17.12 .2019

*Corresponding author: Muhammad Barkindo Umar

\section{Abstract}

This study examines the relationship between internal control system and risk assessment in Board of Internal Revenue in Bauchi State. Data were generated with the aid of necessary information collected from the study through the cross sectional survey through the administered of questionnaire. A total population size of 150 were selected and sample size of 109 was determined using Taro Yamane's formula at 0.05 level of significance. Also, 109 copies of questionnaire were distributed to the respondents, while 87 copies were completed and retrieved. The instruments were validated with reliability above 0.8 co-efficient, using Cronbach Alpha Technique. six research questions and six hypotheses were raised which was tested with spearman's rank order co-efficient of correlation using SPSS 20 version. From the findings, the concept of internal control system creates positive impact on risk assessment and risk financings. In conclusion, internal control system has a significant impact in risk assessment in the Nigerian public sector. Based on the findings and conclusion, it could be recommended that any internal auditor who cannot demonstrate the appropriate skills and knowledge should not undertake work in the area of risk assessment. Furthermore, internal control system should maintain high level of objectivity and independence in carrying out their core function of evaluating and providing management with assurance on risk assessment.

Keywords: Internal control system, Risk Assessment, Public Sector.

Copyright @ 2019: This is an open-access article distributed under the terms of the Creative Commons Attribution license which permits unrestricted use, distribution, and reproduction in any medium for non-commercial use (NonCommercial, or CC-BY-NC) provided the original author and source are credited.

\section{INTRODUCTION}

The effect of internal control system on risk assessment in public sector prevention of fraud cannot be over emphasized as each case of fraud has its devastating effect on not only public sector organization but also the national economy at large. Fraud has racked the economy of this nation, it is now a generally accepted fact that the problem of managing the economy now depends on the ability of the manager to keep this fraud at a distance, if they must succeed.

Public institutions set up by an Act of parliament are by that Act, mandated to provide services or products for public good interest. In developing economy, like Nigeria, public sector represents one of the most dominant economic forces; perhaps due to the fact that government constitutes the largest single business entity and her pattern of expenditure through its various Ministries, Agencies and Departments (MDAs) stimulate a lot of economic activities [1].
No organization whether public or private has the luxury of operating in a risk free environment. Organizations operate in a very complex and competitive environment, facing many risks as well as internal and external forces, continuously hampering organization objectives [2].

So, public institutions in the course of carrying out their constitutional mandate are exposed and vulnerable to numerous risks that threatens their corporate existence and effective service delivery to the public.

Public sector environment is characterized with peculiar and unique challenges such as limited resources, excessive bureaucratic bottleneck, inadequate human and technological capacity, nepotism, political aggressiveness and will, corruption, misappropriation of fund, silo mentality, competing needs and priority and infrastructural backlogs etc. All these dynamics among 
others, increases the risk profile of the public sector as a whole and places an extra duty of care on public sector management to contain risk within acceptable limit, and internal control system has a role to play in minimizing these risk exposures affecting organizational objectives [3].

Hence, the concept of Risk Assessment technique (risk control and risk financing) is a valuable management tool which increases an institution's prospects of success through minimizing negative outcome and optimizing opportunities. Gerrit et al. [4], in his work titled: Risk Management and internal Control in Public Sector emphasized that Risk Management is important to the success of public services. Risk facing entities must be managed to an acceptable level so that objectives can be achieved and a decrease in shareholder value can be avoided [2]. Internal audit which carry an activity of providing constant review and appraisal of the systems and procedures introduced by management with the intention to enable the management to control and utilize their resources properly and effectively plays an important role of risk assessment in an organization [5].

Kokobe \& Gemerhu [6] conducted a research on Risk management techniques and financial performance of insurance companies to find out how risk control and risk financing as a risk management techniques impact on financial performance of firms. Their finding reveals a positive relationship between Risk management techniques(risk control and risk financing) and financial performance of firms, suggesting that companies should adopt enterprise risk assessment that is currently the best practice standard and also apply risk management techniques effectively so as to improve on their return on equity and reducing loss ratios. It is against this framework, that this study is carried out to examine and analyze the role of internal control system on risk assessment of public sector in Nigeria, by providing independent and objective assurance of the effectiveness of risk control and risk financing techniques of risk assessment. Public institutions must change the traditional role of the audit from evaluating internal control to the process of risk assessment and corporate governance. It used to be that internal auditing in the public sector served as a simple administrative procedure comprised mainly of checking accuracy of transactions, pre-payment verification and control, counting assets and reporting on past events to various types of management, but in recent times, government in moving towards high levels of transparency must demonstrate accountability in the use of public money and efficiency in the delivery of services, thus, the need for greater competency and professionalism from internal system to minimize and manage risk [7].

\section{STATEMENT OF PROBLEM}

Public Sector entities are often characterized with different categories of risk, arising as a result of both internal and external factors such as failure of contractors or Government agencies to provide services as required, project delays, cost overruns, inadequate quality standards, delay or failed introduction of new technology, loss or misappropriation of fund through corruption, disruption from industrial action, protest, communal clashes, inconsistent programmed objectives, inadequate contingency plans, failure to innovate, economic changes, environmental damages etc. All of these risk factors among others threaten the corporate existence and effective service delivery of public sector entities [8].

Consequently, this has brought the subject of risk assessment in both government and private institution on the front burner, which has resulted to the development of several government legislations and reforms, such as the Sarbanes Oxley Act in the USA, the Basel II capital and the revised combined code [9] in the U.K. and the code of corporate Governance for public companies (part E) in Nigeria among others, to minimize the risk of future major corporate failure via tighter regulation of internal control system [10]. The effectiveness and efficiency of risk control and risk financing (risk management) seems to pose enormous challenges in various industry, public sector not exempted [11]. Thus, the problems facing public entities in risk assessment as identified in this study are: the problem of an effective risk control measures; the problem of choosing an efficient risk financing measures and the challenge of an independent, objective and professional internal audit assurance regarding the effectiveness and efficiency of risk control and risk assessment.

A conclusion that can be drawn from the State Audit Office's audit and research experience is that even though internal controls system are usually developed for risk assessment in organizations belonging to the central and local government subsystems of public finances, risk assessment techniques are not fully integrated and thus, not effective within the organizational operations [12].

\section{AIM OF THE STUDY}

The aim of this study is to examine the effect of internal control system on risk assessment in Bord of internal revenue in Bauchi State.

\section{RESEARCH HYPOTHESES}

In this research study, six (6) hypotheses, served as a guide and provided focus to this survey which was tested for acceptance or rejection. Thus, the research study was based on the following null hypothetical statements: 
Ho1: Internal control independence has no impact on risk assessment in public entities.

Ho2: Internal control objectivity has no impact on risk assessment in public entities.

Ho3: Internal control competence has no impact on risk assessment in public entities.

Ho4: Internal control independence has no effect in risk financing in public entities.

Ho5: Internal control objectivity has no effect in risk financing in public entities.

Ho6: Internal control competence has no effect in risk financing in public entities.

\section{LITERATURE REVIEW Theoretical Framework}

In this study two theories were selected as guild upon which this study was attached. The theories are agency theory and the institutional theory:

\section{Agency Theory}

In its primitive form, agency theory relates to situations in which one individual (called the agent) is engaged by another individual (called the principal) to act on his/her behalf based upon a designated fee schedule [13]. In the broad sense, whenever one party (principal) depends on the action of another party (agent), agency relationship arises [14]. Jensen \& Meckling [15] define an agency relationship as a contract by which one or more persons (the principal) hire another person (the agent) to perform some service on their behalf, giving the agent some of their decision making power. Agency theory in this context provides the basis to explain the services and responsibilities assigned to the internal audit function. An agency operates under the condition of risk and uncertainty. In effect, the basic agency theory usually assumes that both individuals are risk averse. Under these circumstances, the amount and content of the produced accounting information and other information sources would become a significant issue in risk sharing (risk management) and controlling the agent's actions [13]. Agency theory in this area of study provides the basis to explaining the independent, objective and professional competence required for the role and responsibilities assigned to the internal audit function of risk management [16]. The agency theory postulated that the internal auditor as an agent to his principal is expected to possess those skills and abilities such as professional competence, independence, and objectivity in the performance of the risk management task.
\end{abstract}

\section{Institutional Theory}

Institutional theory in organizational research is mainly concern with understanding the nature and characteristics of an organization from an open system perspective, focusing on how the organization is affected by its environmental interactions [17]. Philip S. [18], in his study on old institutional theory refers organizations to as organisms that adapts to environmental threats. Philip asserted that the internal structure of the organization is constantly under tension with the external environment, with which the organization interacts with to sustain its legitimacy and survival. In this study therefore, the institutional theory provides the theoretical framework on the different applications of risk management processes, approaches and techniques in different field and organizations (private and public) because of the institutional characteristics of these organization. Ignacio C.S. [19], explained the risk management applications in different field of study; that economics and finance study risk by examining the distribution of corporate returns on investment; banking analyze risk with respect to liquidity, credit and capital adequacy; while psychology and sociology interpret risk in terms of behavioral component. Thus, the approach and assessment of risk management in Private Sector entities that is profit driven is different from that of the public sector that is non-profit driven because of the different range of stakeholder the organization is accountable to, and the extent to wish political and social dimension impact on decision making [19]. Thus, the institutional theory underpins the use of the two (2) risk management techniques: risk control and risk financing to evaluating the impact and effect of internal control activities in risk assessment in the selected public sector in Bauchi State Government.

\section{DEFINITION OF INTERNAL CONTROL}

Cook and write [20] define internal control as the system within an organization or company consisting of its plan of organization and the assignment of duties and responsibilities, the design of the accounts and reports and all measures and method to employ:

a. Protect its assets

b. Promote and judge the operational efficiency of the organization activity

c. To communicate managerial policy, encourage and measure compliance.

Other authors define internal control as not only check in internal audit but whole system of control, financial and otherwise [21].

Internal control is examined in the auditing guidelines as the whole system of control, financial and otherwise, established by the management in other to carry on the business of the enterprise in an orderly and efficient manner, ensure as far as possible the completeness and accuracy of the records.

\section{INTERNAL AUDIT}

According to the Institute of Internal Auditors [22], internal auditing is an independent, objective assurance and consulting activity designed to add value and improve an organization's operations. It helps an organization accomplish its objectives by bringing a systematic, disciplined approach to evaluate and 
improve the effectiveness of risk management, control, and governance processes.

This definition reveals the scope of modern internal auditing which includes value for money, evaluation of risk, managerial effectiveness and governance processes.

Internal audit's role in risk assessment involves assessing and monitoring the risks that the organization faces, recommending the controls required to mitigate those risks, and evaluating the trade-offs necessary for the organization to accomplish its strategic and operational objectives.

\section{AUDIT INDEPENDENCE}

According to Stewart \& Subramaniam [23], the motivation for increased interest in the objectivity and independence of internal audit is associated with "the evolving and expanding role of internal audit as key corporate governance mechanism, as well as an internal consultancy service. In this respect, internal auditors occupy the unique position as providers of both assurance services within the organization, and consultancy services to managers."

Vansco et al. [24] noted that without independence, the desired results of the IA cannot be realized. He also concluded that that the role of internal audit requires unrestricted independence in order to perform a variety of duties for the organization they serve. The IPPF attribute standard 1100 which define independence as the freedom from conditions that threaten the ability of the internal audit activity to carry out internal audit responsibilities in an unbiased manner, asserted that the internal audit activity must be independent in performing their work. Independence is fundamental to the reliability of auditor's reports. Those reports would not be credible, and investors and creditors would have little confidence in them, if auditors were not independent both in fact and appearance. The assurance services provided by auditors derive their value and credibility from the fundamental assumptions of independence of mind and independence in appearance [23].

\section{AUDIT OBJECTIVITY}

IIA [25], stated that the core role of internal auditing with regard to enterprise risk management is to provide quality and objective assurance to the board on the effectiveness of risk management. IIA, also asserted that research has shown that the two most important ways that internal auditing add value to the organization is in providing objective assurance that business risks are being managed appropriately, and that the risk assessment and internal control framework is operating effectively.
The IPPF Standards defined Objectivity is an unbiased mental attitude that allows internal auditors to perform engagements in such a manner that they believe in their work product and that no quality compromises are made. The Standards also asserted that Objectivity requires that internal auditors do not subordinate their judgment on audit matters to others. Threats to objectivity must be managed at the individual auditor, engagement, functional, and organizational levels.

\section{AUDIT COMPETENCE}

Competence of internal audit staff is also considered as one of the variables in measuring internal audit in this study. The IPPF attribute standard 1200 propounded that all internal audit work and engagement must be done with proficiency and due care. The internal audit staff must possess the requisite knowledge, skills; competence and professional proficiency needed in carrying out their responsibilities and duties, and must apply the care and skill expected of a reasonably prudent and competent internal audit staff. IPPF defines proficiency as a collective term that refers to the knowledge, skills, and other competencies required of internal auditors to effectively carry out their professional responsibilities. It encompasses consideration of current activities, trends, and emerging issues, to enable relevant advice and recommendations. Internal auditors are encouraged to demonstrate their proficiency by obtaining appropriate professional certifications and qualifications, such as the Certified Internal Auditor designation and other designations offered by The Institute of Internal Auditors and other appropriate professional organizations.

\section{RISK ASSESSMENT}

The concept of risk assessment evolved from the insurance industry where risk financing was the main risk management activity [26].

The concept of risk assessment does not have a generally accepted definition. The Standards of Internal. Audits define risk assessment as the process of identification, evaluation, and control of potential events or situations in order to give reasonable assurance in respect of the achievement of objectives [27]. The Committee of Sponsoring Organizations of the Tread way Commission (COSO),

ERM Integrated Framework [28]: Enterprise risk assessment is a process, effected by an entity's board of directors, management and other personnel, applied in strategy setting and across the enterprise, designed to identify potential events that may affect the entity, and manage risk to be within its risk appetite, to provide reasonable assurance regarding the achievement of entity objectives. 
George L. H. [29], defined risk assessment as the process of planning, organizing, directing, and controlling resources to achieve given objectives when surprisingly good or bad events are possible.

\section{RISK CONTROL}

According to IIA \& RIMS [25], in their work on Risk assessment and Internal Audit: forging a collaborative alliance, risk control was a major evolutional development strategy in risk assessment that combine a few risk functions into an integrated advanced risk management function, focusing primarily on managing insurable hazard losses through prevention and severity decline(reduction). They also added that risk control approach focuses on threat facing the organization.

Vaughan [30], defined risk control as a technique that is designed to minimize, at the least possible costs, those risks to which the organization is exposed to.

Ignacio [19], asserted that risk control are those measures designed and adopted by the organization to minimize those risk which the organization are exposed to.

Risk control are those measures put in place to stop losses from happening (by reducing the number of the accidental losses an organization suffers) or increases the predictability of accidental losses [29]. Risk control is basically concern with putting all organizational or operational risk on check, ensuring that they do not escalate to the point where the organization objectives and survival is threatened. Risk control therefore, is a key component in any organizational strategy. It's important to ensuring longterm organization sustainability and profitability.

Vaughan [30], explained that in the application of risk control within an organization, decision are often made to prevent a risk from occurring, by refusing to accept an activity or business proposal because of the inherent risk, which he referred to as risk avoidance method.

George L. H. [29], opined that when the magnitude of loss is greater than the reward from a risky venture, risk avoidance becomes an important decision to manage such risk. He however asserted that, while exposure avoidance can be a very powerful risk control tool, it can be used only very selectively.

Thus, risk control through risk avoidance utilizes cost-benefit analysis. Pom \& Associates Insurance Brokers in its publication on the fifth pillars of risk control explained that risk avoidance is the best means of loss control. This is because, as the name implies, you're avoiding the risk completely. If your efforts at avoiding the loss have been successful, then there is a $0 \%$ probability that you'll suffer a loss (from that particular risk factor, anyway). This is why avoidance is generally the first of the risk control techniques that's considered. It's a means of completely eliminating a threat.

Also, risk control is measured by how much the organization is able to checkmate and reduce to the barest minimum risk within the system (inherent risk) that cannot be avoided. This risk control measures are referred to as risk reduction method. It is the procedures and policies designed by management to checkmate to negative exposure of an inherent risk within the organization. These procedures and policies are also referred to as internal control measures put in place to prevent or reduce the occurrence of risk within the organization. Vaughan [30], explained that risk reduction measures are designed to reduce the likelihood of loss or the potential severity of the losses that do occur.

\section{RISK FINANCING}

Another variable for measuring risk management examined in this study is Risk financing, which is one of the component of risk management techniques or tools.

It has been argued in several literatures that risk cannot be completely eradicated in an organization and that venturing into any activities of business calls for risk. Inherent in every organization is an unavoidable risk as long as the organization is in existence. Eugenia T. \& Aurelia S [1] asserted that risk is unavoidable and it is permanently inherent in all the activities of all entities. The challenge therefore is what to do with the risk that cannot be avoided. How can the unavoidable risk that is permanently present in an organization be managed? What is the insurable and contractual risk facing the entities? All risks that cannot be avoided or reduced must by definition be transferred or retained through risk financing techniques [30].

The IIA \& RIMS [25] explained that the evolution of risk management function began originally with risk financing which primarily deal with risk transfer, whether through hedging, insurance or some other instruments and is characterized as traditional/defensive risk management. They also asserted that risk financing focuses on insurance, contractual and transaction risks.

George L.H. [29], explained that only exposure avoidance totally eliminates a given loss exposure. Each of the other risk control techniques leaves open the possibility no matter how unlikely or how small of some accidental losses arising from each loss exposure. As long as these possibilities exist, effective risk management calls for arranging one or 
more sources of funds to pay for every possible accidental loss, which is risk financing.

According to Vaughan [30], risk financing consists of those measures or arrangements designed by management to guarantee the availability of funds to meet those losses that do occur as a result of risk that is inherent within the organization.

Global Humanitarian Report [31], defines risk financing a set of measures designed to shift the mobilization of funds away from ad hoc efforts in the wake of a crisis, and towards a risk-informed strategy to secure access to funds in advance of anticipated crisis events, effectively smoothing the financial impact of post-crisis response and recovery over time. And that, Risk financing mechanisms include savings and reserves, access to credit and market-mediated risk transfer products such as insurance and catastrophe bonds.

Risk retention strategy which is an internal risk financing method is taken care of by different means within the organization, which among other means include, reserves, specific budgets or funds set aside to manage those retained risk within the organization or meet the deviation of expected losses[30].

\section{EMPIRICAL LITERATURE REVIEW}

Some empirical studies have been done on this subject matter in some countries of the world.

Gherai et al. [32] did a research on the role of internal control in risk management in the public sectored local entities Case Study Bihor County. Their studies show that the independent assurance of internal control activity on the process of risk assessment was $66.6 \%$. The study also identified some shortcomings in their analysis, among which was the lack of specialist personnel, and the conclusion was that the problem of lack of professional personnel in the field of public internal control at the national level is reflected in the local plan generated by the current economic situation of the country.

Gherai \& Balaciu [32], in their work which focuses on the Role of Internal Control in Risk

Management in the public sector and local entities in Bihor County, Romania explained that based on responses from 49 entities from public sector, the result of the study show that the public internal auditors know they can play an important role in the risk management, but there are a number of other activities which must be conducted within the organization. So, they tend to understand the concept of risk assessment and risk management process, where it is carried out, and of the role they can play in improving and activity, however, issues of disposable incomes allocated to activity, and enough personnel specializing in the field, as well as a lack of interest of management to increase the efficiency and profit of the public internal control activity, are issues that impede performance and risk management.

Elizabeth \& Diane [22], conducted a global assessment based on IIA's global internal control survey on the nine elements required for internal control effectiveness in the public sector and found out that almost all Chief Audit Executives respondents (92\%) agreed or strongly agreed that independence was a key factor for the internal control activity to add value, and that In response to a question related to coercion, about a fifth of the internal control respondents (21\%) indicated that they had been subject to coercion (extreme pressure) to change a rating or assessment or to withdraw a finding in an internal control report. The highest percentage was in Africa (31\%), and the lowest was in the United States and Canada (13\%).

A related study carried out in the Nigerian experience with the objective of enhancing good governance in the public sector through internal control function by Taiwo et al. [33] showed that the effectiveness of Internal Control Function (ICF) in Nigerian public sector organizations was moderate since internal control system in the public organizations was not absolutely independent and professional competence was limited due to the challenge of insufficient funds to successfully carry out its duties. Moreover, the study revealed that ICF had significant and positive effect on the quality of service delivery and management of resources in the public organizations.

Udeh \& Eugene [1] in their study on the evaluation of the effectiveness of internal control in the Nigeria public sector found and observed the implicit existence of effective internal control procedures to safeguard assets of organizations, but that there is the need for adequate internal control personnel and training, as this would increase their effectiveness. It is not sufficient in itself to have a system of risk assessment with risk management measures developed, but also to have these risk measures developed implemented and monitor through the risk management process, as this will guarantee public sector efficiency.

\section{RESEARCH METHODS Research Design}

The study adopted quasi-experimental design. The quasi-experimental research design was adopted in alignment with cross sectional survey. This is because all the entire population or variables are outside the control of the researcher and cannot be studied, so a survey was more appropriate. The research was descriptive in nature. According to Saunders et al. [34], a descriptive cross sectional survey in nature, is a method of social affairs data that examines the people who are the object of the examination and having a place with an agent test, through an institutionalized 
addressing strategy with the point of contemplating connections between variables at a particular time.

This research design is thus, most appropriate since the objective of the study is to examine the role and effect of internal audit in risk management. Sample and Sampling Techniques, The target population of this study consists of selected departments in Board of Internal Revenue (BIR). Thus, for ease and convenience the department was merged and categorized into ten (10) groups. In all the ten (10) group (BIR) that were chosen, respondents from each were selected purposively with their attendants to include the numbers of employee from the cluster. Stratified random sampling techniques were adopted in the choice of the respondents for this study. A total population size of 150 and sample size of 109 was determined using Taro Yamane's formula at 0.05 level of significance. Also, 109 copies of questionnaire were distributed to the respondents, while 90 copies were completed and retrieved.

\section{METHODS OF DATA COLLECTION}

Semi-structured questionnaire was used as instrument to collect data for the study. The research questionnaire was designed by the researcher and coined from the early work of Brink [35] and Dennison [36] based on the specific objectives, research questions, hypotheses and information in this study.

\section{METHODS OF DATA ANALYSIS}

The researcher assembled all the returned copies of the questionnaire, sort out the ones that are properly filled and separate them from the ones not properly filled. The questionnaire was coded for analysis using SPSS version 20. Descriptive statistics of percentage and inferential statistics were used to analyze the questionnaire instrument. Also, Spearman's Rank Order Correlation Co-efficient were used for data analysis.

\section{Model Specification}

Two models are formulated for this study, which is specified below:

$\mathrm{RC}=\alpha+\beta 1 \mathrm{AI}+\beta 2 \mathrm{AO}+\beta 3 \mathrm{AC}+\varepsilon \mathrm{i}$

$\mathrm{RF}=\alpha+\beta 1 \mathrm{AI}+\beta 2 \mathrm{AO}+\beta 3 \mathrm{AC}+\varepsilon \mathrm{i}$

Where,

$\alpha$, is the intercept of relationship or parameter estimates in the model

$\beta$, is the regression coefficient or parameter estimates for the model

$\varepsilon i$, is the error terms or residual value

AI is Audit Independence; AO is Audit Objectivity; AC is Audit Competence

$\mathrm{RC}$ is Risk Control; RF is Risk Financing.

\section{RESULTS AND DISCUSSION Test of Hypotheses}

The statistical tool used to test the hypothesis was spearman's rank co-efficient of correlation. The study adopted the 0.05 level of significance as a criterion for significant or non-significant effect for the acceptance or rejection of the hypotheses.

Hypothesis 1 (Ho1): Internal control independence has no impact on risk control in public entities.

The Correlation was significant at the 0.05 level (2tailed).

The correlation coefficient (r) was 0.865 , which means it is positively correlated and strong relationship exist among the variables. The significant value of $0.040(\mathrm{p}<0.05)$ shows a significant relationship.

Thus, the null hypothesis was rejected and the alternate hypothesis accepted which states; Internal control Independence has an impact on risk control in public entities. This indicates that internal control independence has positive impact in Risk assessment in the Nigerian public sector.

Hypothesis 2 (Ho2): Internal control objectivity has no impact on risk control in public entities.

The Correlation was significant at the 0.05 level (2-tailed).

Since the correlation coefficient (r) was 0.845 , which means it is positively correlated, and strong relationship exist among the variables. The significant value of $0.044(\mathrm{p}<0.05)$ shows a significant relationship. Thus, the null hypothesis was rejected and the alternate hypothesis accepted which states;

Internal control objectivity has an impact on risk control in public entities. This indicates that internal control objectivity has positive impact in Risk assessment in the Nigerian public sector.

Hypothesis 3 (Ho3): Internal control competence has no impact on risk control in public entities.

The Correlation was significant at the 0.05 level (2-tailed).

Since the correlation coefficient (r) was 0.872 , which means it is positively correlated, but strong relationship exists among the variables. The significant value of $0.044(\mathrm{p}<0.05)$ shows a significant relationship. Thus, the null hypothesis was rejected and the alternate hypothesis accepted which states; internal control competence has an impact on risk control in public entities. This indicates that internal control 
competence has positive impact in Risk assessment in the Nigerian public sector.

Hypothesis 4 (Ho4): Internal control independence has no effect in risk financing in public entities.

The Correlation was significant at the 0.05 level (2-tailed).

Since the correlation coefficient (r) was 0.855 , which means it is positively correlated, and strong relationship exist among the variables. The significant value of $0.041(\mathrm{p}<0.05)$ shows a significant relationship. Thus, the null hypothesis was rejected and the alternate hypothesis accepted which states;

Internal control Independence has an impact on risk financing in public entities. This indicates that internal control independence has positive impact in Risk assessment in the Nigerian public sector.

Hypothesis 5 (Ho5): Internal control objectivity has no effect in risk financing in public entities.

The Correlation was significant at the 0.05 level (2-tailed).

Since the correlation coefficient (r) was 0.852 , which means it is positively correlated, and strong relationship exist among the variables. The significant value of $0.046(\mathrm{p}<0.05)$ shows a significant relationship. Thus, the null hypothesis was rejected and the alternate hypothesis accepted which states;

Internal control objectivity has an impact on risk financing in public entities. This indicates that internal control objectivity has positive impact in Risk assessment in the Nigerian public sector.

Hypothesis 6 (Ho6): Internal control competence has no effect in risk financing in public entities. level (2-tailed).

The Correlation was significant at the 0.05

Since the correlation coefficient (r) was 0.743 , which means it is positively correlated, and strong relationship exist among the variables. The significant value of $0.032(\mathrm{p}<0.05)$ shows a significant relationship. Thus, the null hypothesis was rejected and the alternate hypothesis accepted which states;

Internal control competence has an impact on risk financing in public entities. This indicates that internal control competence has positive impact in Risk assessment in the Nigerian public sector.

\section{DISCUSSION OF FINDINGS}

The research findings reveals that a significant relationship exist between internal control and risk Assessment, and that internal control has a role to play in the risk control and risk financing of an Organization, which therefore, asserts that internal control activities has significant impact in risk assessment. From the research study, the respondents agreed vividly, that internal control independence enhances risk control and risk financing which were used as a measure of risk management; and the hypotheses (hypothesis 1 and 4) test findings shows that there is a strong and positive significant impact of internal control independence on risk control and risk financing. This indicates that internal audit independence has positive impact in Risk assessment in the Nigerian public sector. For an effective evaluation of risk control and risk financing in an organization, internal control that has a role to play in the risk control and risk financing of an organization must be independent. This finding is in line with earlier findings that the independence of internal control department and the level of authority to which the internal audit staff report are the important criteria influencing the objectivity of its work, and that internal control independence is more crucial to the effectiveness of the internal control system, as it protects the auditor from pressure or intimidation, and increases the reliability and credibility of the auditing work [37]. Independence allows the internal control auditor to carry out his audit work and be perceived to carry out such conduct work without interference by the entity under audit.

The respondents in this research study agreed that internal control objectivity influences risk control and risk financing in an organization; and the hypotheses (hypothesis 2 and 5) test findings shows that there is a strong and positive significant impact of internal control objectivity on risk control and risk financing.

This indicates that internal audit objectivity has positive impact in Risk assessment in the Nigerian Public sector. For an effective evaluation of risk control and risk financing in an organization, internal

Control auditor who has a role to play in the risk control and risk financing of an organization must be objective. This is in agreement with the assertion of the Institute of Internal Audit that the core role of internal.

Control auditing with regard to enterprise risk assessment is to provide quality and objective assurance to the board on the effectiveness of risk management, and that the two most important ways that internal control add value to the organization is in providing objective assurance that business risks are being managed appropriately, and that the risk management 
and internal control framework is operating effectively [25].

The respondents in this research study also vividly agreed that internal control competence influences risk control and risk financing in an organization; and the hypotheses (hypothesis 3 and 6) test findings shows that there is a strong and positive significant impact of internal control competence on risk control and risk financing. This indicates that internal control competence has positive impact in Risk assessment in the Nigerian public sector. For an effective evaluation of risk control and risk financing in an organization, internal control auditor who has a role to play in the risk control and risk financing of an organization must be qualified, experienced and competent. This is in line with the assertion of IPPF attribute standard 1200 that all internal control audit work and engagement must be done with proficiency and due care, and that the internal control audit staff must possess the requisite knowledge, skills, competence and professional proficiency needed in carrying out their responsibilities and duties, and must apply the care and skill expected of a reasonably prudent and competent internal audit staff. IIA [25], also added in the area of skill and knowledge need of internal auditing by stating that any internal control auditor who cannot demonstrate the appropriate skills and knowledge should not undertake work in the area of risk assessment. Thus, internal control auditor and risk managers should share knowledge, skills and value, both for example in understanding corporate governance requirements; having project management, analytical and facilitation skills and value; having a healthy balance of risk rather than extreme risk taking or avoidance behavior.

\section{SUMMARY}

The empirical scope of the research is outlined to the impact of internal control activities in risk assessment of public entities in Nigeria with the exclusion of the private sector from the research study. And In evaluating and measuring the variables in this study, Internal control as an independent variable was limited to the use of independence, objectivity and competence as measuring alternatives, while risk assessment was evaluated and measured using risk control and risk financing. The study was limited to the use of validated primary data for analysis.

The study revealed that the internal control had an impact on risk assessment as far as respondents are concerned in Bauchi State Board of internal revenue. The independent variable in this study is internal control system. The alternatives are internal control independence, internal control objectivity and internal control competence. While the dependent variable for this study is Risk assessment. The measures of Risk assessment which includes: risk financing and risk control. This study also considered the relationship between the predictor variable and standard variable. The ex-post facto design was used in line with purposive sampling techniques. Findings reveal that there exist positive relationships between the predictor variable and criterion variable alternatives.

\section{CONCLUSION}

Risk assessment is a fundamental element of corporate governance. Management is responsible for establishing and operating the risk assessment framework on behalf of the board. Enterprise with risk assessment brings many benefits as a result of its structured, consistent and coordinated approach. Internal control core role in relation to risk assessment should be to provide an independent, objective and professional assurance to management and to the board on the effectiveness of risk assessment. When internal control auditing extends its activities beyond this core role, it should apply certain safeguards, including treating the engagements as consulting services and, therefore, applying all relevant Standards. In this way, internal control auditing will protect its independence and the objectivity of its assurance services. Within these constraints, internal control will be able to carry out its risk assessment function effectively. The effectiveness of a risk control system and the efficiency of a risk financing option require an independent, objective and competent internal control function, as the study shows that there is a positive correlation between internal control and risk assessment techniques.

\section{RECOMMENDATIONS}

Based on the results of findings, the following are recommendations for future implementation. It should be clear that management remains responsible for risk assessment. The nature of internal control responsibilities should be documented in the internal control deed and approved by the audit committee. Management, government and other stakeholders should provide internal control with the necessary support and environment that guarantee their independence, objectivity and competence in the discharge of their core risk assessment role without undue influence and interference. Internal control sysem should not take any risk decision on behalf of management. Internal control should provide advice, challenge and support to management's decision making, as opposed to taking risk assessment decisions themselves.

Internal control should maintain high level of objectivity and independence in carrying out their core function of evaluating and providing management with assurance on risk assessment, and should observe all safeguards to mitigate threats on audit objectivity and independence. This will guarantee integrity, reliability and credibility of assurance report on risk assessment provided. 
Furthermore, Government should ensure that Board of internal revenue imbibes a culture of risk assessment within the organization by ensuring an effective risk control system and an efficient risk financing options.

\section{REFERENCES}

1. Udeh, S. N., \& Eugene O. N. (2016). Evaluation of the effectiveness of internal audit in the Nigeria public sector. European journal of business, economics and accountancy. 4(3). progressive academic publishing, UK. Retrieved from www.idpublications.org

2. Coetzee, G.P. (2012). Advance internal audit, (3rd ed.). South Africa: LexisNexis.

3. Sridhar, R. (2003). Internal auditing: history, evolution and prospect. IIA research foundation, Florida, U.S.A.

4. Gerrit, S., Christian, D. V., \& Diane V. G. (2010). Risk management and internal control in the public sector: An in-depth analysis of Belgian social security public Institutions. A paper presented at the 2nd European risk conference, Milan.

5. Mu'azu, S. B., \& Siti, Z. S. (2012). The

Relationship between risk management and internal audit effectiveness at local government level.

Journal of social and development sciences,

Malaysia. Retrieved from: http://www.ifrnd.org/admin/jsds/27.pdf.

6. Kokobe, S.A., \& Gemechu, D. (2016). Risk Management Techniques and Financial Performance of Insurance Companies. International Journal of Accounting Research.

7. Deloitte. (2011). Internal audit in public sector: The quiet revolution. Retrieved from http://www.deloitte.com. Department of Administrative Reforms and Public Grievances (DAPRG). Internal control and risk management framework (II). Retrieved from https:// darpg.gov.in/documents.

8. Adeniji, A.A. (2011). Auditing and investigations. Ikeja, Nigeria: wyse associates limited.

9. Creswell, J. W., Plano Clark, V. L., Gutmann, M. L. \& Hanson, W. E. (2003). Advanced mixed methods research design. Handbook on mixed methods in the behavioral and social sciences (pp. 209 240). Thousand Oaks, CA: Sage Publications.

10. Margareth Wood. (2001). A contingency theory perspective on the risk management control system within Birmingham City Council: a CRIS discussion paper series, University of Nottinham, England.

11. Robert, Wolf. (2008). The evolution of enterprise risk management. The actuary magazine, issued by the society of actuaries, 5(2). Retrieved from https://www.soa.org/library.

12. Domokos, L., Nyéki, M., Jakovác, K., Németh, E., \& Hatvani, C. (2015). Kockázatelemzés és kockázatkezelés a közszférában és a közpénzügyi ellenőrzésben $=$ Risk Analysis and Risk Management in the Public Sector and in Public Auditing. Pénzügyi szemle/public finance quarterly, 60(1), 7-28.

13. Namaz, M. (2012). Role of the agency theory in implementing management's control. Journal of Accounting and Taxation, 5(2), 38-47. Retrieved from http://www.academicjournals.org/JAT.

14. NAO. (2011). Managing risk in government. Financial management and reporting, U.K. Retrieved from: www.nao.org.uk/ginancialmanagement.

15. Pratt, John., \& J. Zeckhauser, Richard. (1985). Principals and Agents: The Structure of Business. Retrieved

from https://www.researchgate.net/publication/24724996 7.

16. Jensen, M., \& Meckling, H. (1976). Theory of the firm: Managerial behavior, agency costs and ownership structure. Journal of Financial Economics. 3. 305-360. 10.1016/0304405X(76)90026-X. Retrieved from https://www.researchgate.net/.../222453506

17. Vargas-Hernandez, J., \& Adams, W. T. (1994). Genetic relationships between wood density components and cambial growth rhythm in young coastal Douglas-fir. Canadian journal of forest research, 24(9), 1871-1876.

18. Meyer, J.W., \& Rowan, B. (1977). Institutionalized Organizations: Formal Structure as Myth and Ceremony." The American Journal of Sociology, 83(2): 340-363.

19. Philip, S. (1948). Foundations of the Theory of Organization. American Sociological Review, 13(1): 2535.

20. Ignacio C. S. (2013). Risk management theory: the integrated perspective and its application in the public sector. Estado, Gobierno, Gestión Públication, 21(2013), 89-126.

21. Acheson, K. J., Campbell, I. T., Edholm, O. G., Miller, D. S., \& Stock, M. J. (1980). The measurement of food and energy intake in manan evaluation of some techniques. The American Journal of Clinical Nutrition, 33(5), 1147-1154.

22. Ahwood, F. A. stein, N.D. (1986): De Paula Auditing.

23. Elizabeth, M., \& Diane V. G. (2014). Nine elements required for internal audit effectiveness in the public sector. An IIA research foundation research report, Florida, U.S.A.

24. Stewart, J., \& Subramanian, N. (2010). Internal audit independence and objectivity: Emerging research opportunities. Managerial auditing journal. Emerald Group Publishing, 25(4),328-360.

25. Abiola, J. O. (2015). Audit expectation gap: Auditors in unending role conflict. (thesis). Retrievedfrom https://www.ajol.info/index.php/ijdmr/article/down load/120974/110403. 
26. IIA \& RIMS. (2012). Risk management and internal audit: forging a collaborative alliance, an executive report published by risk and insurance management society (RIMS), U.S.A.

27. Gerry Dickinson. (2001). ERM: Its origin and conceptual foundation. The Geneva papers on risk and Insurance, 26(3)360-366.

28. Eugeria, T., \& Aurelia S. (2009). Internal audit and risk management in public sector entities, between tradition and actuality. Annales Universitatis Apulensis Series Oeconomica, 11(1).

29. COSO. (2004). Enterprise risk management integrated framework: Executive summary. Retrieved from http://www.coso.org.

30. George, L. H. (2009). Risk Management why and how. An illustrative introduction to risk management for business executives. IRMI Inc. Retrieved from: www.irmi.com

31. Vaughan, E. J., \& Vaughan, T. (2008). Fundamentals of Risk and Insurance. John Wlley \& Son Inc. New Jersey, U.S.A. https://www.wikipedia.org

32. Global Humanitarian Assistance Report.(2014). Future humanitarian financing: What is risk financing? Retrieved from: www.globalhumanitarianassistance.org/report/ghareport.
33. Gherai, D. S., \& Balaciu D. E. (2004). Role of internal auditing in risk management in public sector and local entities - a case study on Bihor County, Romania, department of finance \& accounting, University of Oradea.

34. Asaolu, T. O., Adedokun, S. A., \& Monday, J. U. (2016). Promoting good governance through internal audit function (IAF): The Nigerian experience. International Business Research, 9(5), 196-204.

35. Saunders, M., Lewis, P., \& Thornhill, A. (2007). Research methods for business students. 4th edi. Edinburgh Gate, Harlow, Financial Times Prentice Hall.

36. Marquette University. (2019). Risk management: what is Risk management? Marquette University publication. Retrieved from:https://www.marquette.edu/riskunit.

37. John, M. (2014). Measuring control effectiveness. LHS businrss control, Hertfordshite, England. Retrieved from www.lhscontrol.com.

38. Beasley, M.S., Branson, B. C., \& Hancock, B. V. (2010). Are you identifying your most significant risks? Strategic Finance journal, 92(5): 29-35. Retrieved from http://www.hbs.edu/faculty/Publication. 